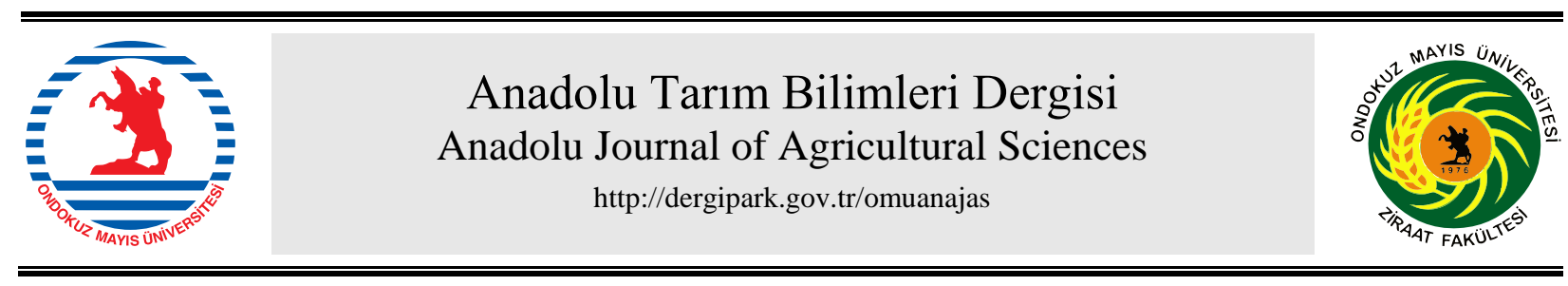

Araştırma/Research

Anadolu Tarım Bilim. Derg./Anadolu J Agr Sci, 34 (2019)

ISSN: $1308-8750$ (Print) (Online)

doi: $10.7161 /$ omuanajas.557976

\title{
Konvansiyonel ve organik çay tarımı uygulamalarının bazı toprak kalite parametreleri ve erozyona duyarlılık üzerine etkileri
}

\author{
Nutullah Özdemir*, Tevhide Atalay \\ Ondokuz Mayıs Üniversitesi, Ziraat Fakültesi Toprak Bilimi ve Bitki Besleme Bölümü, Samsun/Türkiye \\ "Sorumlu yazar/corresponding author: nutullah@omu.edu.tr
}

Geliş/Received 28/04/2019 Kabul/Accepted 02/10/2019

\begin{abstract}
ÖZET
$\mathrm{Bu}$ araştırma, Rize ili koşullarında konvansiyonel ve organik çay tarımı uygulamalarının bazı toprak kalite parametreleri ve erozyona karşı duyarlılık üzerine etkilerini belirlemek üzere yürütülmüştür. Çalışmada, aynı hat üzerinde ve farklı konumlarda yer alan, organik ve geleneksel tarım uygulamalarının yapıldığı çay bahçelerinden alınan 40 adet yüzey $(0-20 \mathrm{~cm})$ toprak örneği kullanılmıştır. Toprak örnekleri üzerinde yapılan analiz ve değerlendirmeler sonucunda konvansiyonel ve organik tarım uygulamalarının toprak kalite parametreleri üzerine etkilerinin konumdan etkilendiği saptanmıştır. Genelde yüksek rakımlarda yer alan parsellere ait örneklerin kil ve organik madde içeriklerinin daha yüksek olduğu, erozyona karşı daha dirençli bir yapıda oldukları görülmüştür. Konvansiyonel tarım uygulamalarının yapıldığı parsellerin organik tarım uygulamalarının yapıldığı parsellere göre ortalama olarak daha uygun toprak kalite koşullarına sahip oldukları görülmüştür.
\end{abstract}

Effects of inorganic and organic tea farming practices on some soil quality parameters and erodibility

\section{ABSTRACT}

This research was carried out to determine the effects of organic and inorganic tea farming practices on some soil quality parameters and erodibility under Rize province condition. The study was done using 40 surface soil samples $(0-20 \mathrm{~cm})$ taken from the orchards having organic and conventional tea farming practices located on the same line and different positions. According to the analyses of the soil samples and evaluations, effects of organic and conventional farm practices on soil quality parameters were influenced by the positions. Generally, it was seen that the samples from the plots located at high elevation were rich with clay and organic matter contents and more resist to erodibility. The plots having conventional farm practices had more suitable soil quality conditions compared with the plots having organic farm practices.

Anahtar Sözcükler: Erozyona duyarlilık, İnorganik tarım, Organik tarım, Toprak kalite parametreleri

\section{Giriş}

Çay (Camellia sinensis), çaygiller (Theaceae) familyasından nemli iklim koşullarında yetiştirilebilen, çalı şeklinde, çatallanma yeteneği yüksek, devamlı yeşil kalabilen, yaprak ve tomurcukları içecek maddesi üretiminde kullanılan (Anonim, 2014), ülkemizde ve dünyada sudan sonra en fazla tüketilen ikinci içecektir. Çay bitkisi iklim ve toprak istekleri açısından seçici olup verim ve kalite yönünden tarımsal uygulamalardan önemli ölçüde etkilenmektedir (Ray ve Mukhopadhyay, 2012).

Saha ve ark., (2014) dört farklı yeşil gübre bitkisinin, Turan ve ark., (2015), sonbahar döneminde
Uygulanan Lifepower organik toprak düzenleyicisi ve ilkbahar döneminde uygulanan Life NP mikrobiyal siv1 yaprak üst gübresinin, Ray ve Mukhopadhyay (2012) konum, organik ve organik olmayan yetiştiriciliğin çay bitkisinin gelişimi, bazı verim unsurları ile toprak kalite parametreleri üzerine ektilerini irdelemişlerdir. Araştırıcılar organik ve inorganik gübre uygulamalarının bitki gelişimi kontrole göre artırdığını, etkinin gübre çeşitlerine göre değişim gösterdiğini, arazi konumunun ve uygulamaların toprak kalite parametrelerini etkilediğini belirtmişlerdir.

Toprakların erozyona uğrama eğilimleri, kalite unsuru olarak değerlendirilen parametrelerden biri olup arazi ve toprak yönetimi, toprak özellikleri (toprak tekstürü, strüktürü, organik madde içeriği, kimyasal bileşimi), topoğrafya ve iklimsel faktörlerden 
etkilenmekte ve dinamik bir karakter taşımaktadır (Öztürk, 2013). Erozyon oranı, eğer toprak yüzeyi sürekli örtülü olacak şekilde üretim yapılırsa, toprak işlemede uygun teknikler kullanılır ve muhafaza tedbirleri uygulanırsa düşer (Özdemir, 2013).

Toprak erozyonu yüzey toprağını uzaklaştırır. Sonrasında yapılan işleme yüzeyin altındaki toprağı pulluk katmanı ile birleştirir. Bunun bir sonucu olarak da yüzey toprağının kalite parametreleri değişir. Toprağın organik karbon içeriği, azot ve ekstrakte edilebilir fosfor içerikleri azalır ve Ap horizonunun altında bir Bt horizonu mevcut ise kil içeriği artar, hacim ağırlığı yavaşça artar ve doygun hidrolik iletkenlik azalır (Lowery ve ark.,1995; Mokma ve ark., 1996). Kabuk oluşumu, su infiltrasyonunun ve elverişli su kapasitesinin azalması, besin elementlerinin kaybı ile topraktaki biyolojik çeşitlilikteki azalma toprak kalitesini olumsuz yönde etkilemektedir (Özdemir, 2013).

Leaungvutivirog ve ark., (2002), yürüttükleri bir araştırmada farklı gübrelerin (kompost, ahır gübresi, kimyasal gübreleme, yeşil gübreleme ve çeltik samanı) toprakların kimyasal ve mikrobiyolojik parametreleri ile misir bitkisinin verimi üzerine etkilerini irdelemişlerdir. Çalıșma sonucunda kompost, ahır gübresi ve çeltik samanı uygulamalarının kimyasal gübrelere göre toprakların organik madde içeriğini daha fazla arttırdığı, mısır veriminin kontrolle karşılaştırıldığında kimyasal gübre uygulamasında daha fazla olduğu fakat organik gübrelerden elde edilen verimden daha az olduğunu saptanmışlardır.

Çay üretimi Doğu Karadeniz bölgemizde ve uzun yıllardır konvansiyonel yöntemle yürütülmektedir. Konvansiyonel tarım uygulamaları içerisinde yoğun kimyasal gübrelerin kullanımı bir taraftan doğal kaynakların sürdürülebilir şekilde kullanımını kısitlarken diğer taraftan toprak kalitesinin bozulmasına ve erozyonun tetiklenmesine sebep olmaktadır. Erozyonun tetiklenmesi; toprak kayb1, su kayb1, su yapılarının sediment ile dolmasına, çevre kirlenmesi ve temiz su kullanım maliyetinin artışı ve verim kaybı gibi problemlere sebep olmaktadır (Akçanal ve Ödün 2013; Turan ve ark., 2015). Bu araştırma organik ve inorganik çay tarımı uygulamalarının bazı toprak kalite parametreleri ve erozyona duyarlılık üzerine etkilerini belirlemek üzere yürütülmüştür.

\section{Materyal ve Yöntem}

Araştırma alanı, Karadeniz bölgesinde Rize ili Çayeli ilçesi Senoz Vadisi'ndeki bölgede $41^{\circ} 5^{\prime}$ 24.5508" Kuzey ve 40 $40^{\circ}$ 39.1260" Doğu GPS koordinatları arasında ve 10-720 m rakımlarında yer almakta olup doğusunda Pazar, güneyinde Çamlıhemşin ve İkizdere, batısında Rize merkez ilçeleri ile kuzeyinde Karadeniz yer almaktadır. Rize'nin $18 \mathrm{~km}$ doğusunda yer alan ilçenin yüzölçümü $442 \mathrm{~km} 2$. Yüzey $(0-20 \mathrm{~cm})$ toprak örneklerinin (20 organik, 20 konvansiyonel) alındığı parseller (Çizelge 1) Yeşiltepe köyüne bağlı Kaptanpaşa, Ayışığı, Arakenar, Sabuncular, Madenli, İncesirt, Çaybaşı ve Habiboğlu mahalle sınırları içerisinde yer almaktadır (Anonim 2018).

Çizelge 1. Toprak örneklerinin alındıkları yerler

\begin{tabular}{|c|c|c|c|c|c|}
\hline \multirow{2}{*}{$\begin{array}{l}\text { Örnek } \\
\text { No }\end{array}$} & \multicolumn{2}{|c|}{ Konvansiyonel Tarım } & \multirow{2}{*}{$\begin{array}{l}\text { Örnek } \\
\text { No }\end{array}$} & \multicolumn{2}{|l|}{ Organik Tarım } \\
\hline & Alındığ1 rakım & Kullanılan gübre & & Alındığ 1 rakım & Kullanılan gübre \\
\hline 1 & 400 & NPK(25:5:10) & 21 & 10 & Ahır-çay çöpü \\
\hline 2 & 400 & NPK(25:5:10) & 22 & 10 & Ahır-çay çöpü \\
\hline 3 & 400 & NPK(25:5:10) & 23 & 30 & Ahır-çay çöpü \\
\hline 4 & 400 & NPK(25:5:10) & 24 & 30 & Ahır-çay çöpü \\
\hline 5 & 420 & NPK(25:5:10) & 25 & 50 & Ahır-çay çöpü \\
\hline 6 & 420 & NPK(25:5:10) & 26 & 50 & Ahır-çay çöpü \\
\hline 7 & 440 & NPK(25:5:10) & 27 & 80 & Ahır-çay çöpü \\
\hline 8 & 440 & NPK(25:5:10) & 28 & 80 & Ahır-çay çöpü \\
\hline 9 & 470 & NPK(25:5:10) & 29 & 100 & Zenginleşt.çay çöpü \\
\hline 10 & 470 & NPK(25:5:10) & 30 & 100 & Zenginleşt.çay çöpü \\
\hline 11 & 510 & $\operatorname{NPK}(25: 5: 10)$ & 31 & 120 & Mikrobiyal \\
\hline 12 & 510 & $\operatorname{NPK}(25: 5: 10)$ & 32 & 120 & Mikrobiyal \\
\hline 13 & 530 & NPK(25:5:10) & 33 & 180 & Mikrobiyal \\
\hline 14 & 530 & $\operatorname{NPK}(25: 5: 10)$ & 34 & 180 & Mikrobiyal \\
\hline 15 & 550 & $\operatorname{NPK}(25: 5: 10)$ & 35 & 210 & Ahır \\
\hline 16 & 550 & $\operatorname{NPK}(25: 5: 10)$ & 36 & 210 & Ahır \\
\hline 17 & 700 & $\operatorname{NPK}(25: 5: 10)$ & 37 & 220 & Ahır \\
\hline 18 & 700 & $\operatorname{NPK}(25: 5: 10)$ & 38 & 220 & Ahir \\
\hline 19 & 720 & NPK(25:5:10) & 39 & 240 & Ahir \\
\hline 20 & 720 & NPK(25:5:10) & 40 & 240 & Ahir \\
\hline
\end{tabular}


Toprak tekstürünün belirlenmesinde Bouyoucos hidrometre (Demiralay, 1993); toprak reaksiyonun tespitinde (1:2.5) cam elektrodlu pH-metre aleti (Bayrakl1, 1987); elektriksel iletkenliğin belirlenmesinde $\mathrm{pH}$ ölçümünün yapıldığı örneklerde cam elektrodlu elektriksel iletkenlik aleti kullanılarak (Bayraklı, 1987); organik madde miktarının belirlenmesinde Walkley-Black yöntemi (Kacar, 1994); tarla kapasitesi $(0.33 \mathrm{~atm})$ ve solma noktasindaki $(15.0$ atm) nem içerikleri basınçlı tabla (Demiralay, 1993), kireç içeriği Scheibler Kalsimetre (Kacar 1994); katyon değişim kapasitesi (KDK) "Bower" yöntemi (U.S Salinity Lab. Staff, 1954); Yarayış̧ı su içeriği tarla kapasitesindeki ve solma noktasındaki su içeriği değerlerinden yararlanılarak (Demiralay, 1993); Toprak aşınım faktörü Wischmeir ve Smith (1978), tarafından geliştirilmiş olan eşitlikten yararlanılarak (Özdemir, 2013); Agregat stabilitesi (AS) Islak Eleme (Demiralay,
1993); dispersiyon oranı (DO) süspansiyon ve mekanik analizde ölçülen silt + kil fraksiyonlarının hidrometreyle ölçüm sonuçlarından yararlanılarak (Ngatunga ve ark., 1984); Erozyon oranı dispersiyon oranı, kil içeriği ve tarla kapasitesinde tutulan nem içeriği değerlerinden faydalanılarak belirlenmiştir (Ngatunga ve ark., 1984) belirlenmiştir.

\section{Bulgular ve Tartışma}

\subsection{Konvansiyonel ve organik tarm yapılan toprakların bazı kalite parametreleri}

Konvansiyonel ve organik tarım yapılan çay parsellerinden alınan toprak örneklerinde belirlenen fiziksel ve kimyasal analiz sonuçlarına ait tanımlayıcı istatistikler Çizelge 2'de verilmiştir.

Çizelge 2. Konvansiyonel ve organik çay tarımı yapılan alanlara ait tanımlayıcı istatistikler $(n=40)$

\begin{tabular}{|c|c|c|c|c|c|c|c|c|}
\hline \multirow{2}{*}{$\begin{array}{l}\text { Toprak } \\
\text { Özellikleri }\end{array}$} & \multicolumn{4}{|c|}{ Konvansiyonel çay tarım } & \multicolumn{4}{|c|}{ Organik çay tarımı } \\
\hline & Minimum & Maksimum & Ortalama & Std. sapma & Minimum & Maksimum & Ortalama & Std. sapma \\
\hline Kum, \% & .43 .47 & 72.48 & 59.983 & 8.6199 & 51.78 & 75.99 & 65.822 & 6.0243 \\
\hline Silt, \% & 16.56 & 30.39 & 22.563 & 4.9901 & 11.74 & 26.99 & 20.533 & 5.1101 \\
\hline Kil, \% & 10.91 & 26.18 & 18.207 & 4.4480 & 8.28 & 23.52 & 13.643 & 5.4150 \\
\hline $\mathrm{pH}(1: 2.5)$ & 4.12 & 6.72 & 5.041 & 0.7643 & 4.5 & 7.5 & 5.367 & 0.9620 \\
\hline $\mathrm{EC}, \mathrm{dS} \mathrm{m}^{-1}$ & 0.265 & 0.818 & 0.452 & 0.169 & 0.579 & 0.666 & 0.319 & 0.168 \\
\hline $\mathrm{OM}, \%$ & 4.19 & 13.51 & 8.7545 & 3.5995 & 2.19 & 10.65 & 5.763 & 2.5847 \\
\hline $\mathrm{TK}, \%$ & 17.98 & 37.75 & 27.6445 & 5.0930 & 13.21 & 24.73 & 17.907 & 3.2803 \\
\hline $\mathrm{SN}, \%$ & 11.7 & 28.10 & 18.413 & 4.489 & 6.08 & 17.97 & 10.04 & 3.184 \\
\hline $\mathrm{KDK}, \mathrm{me} 100 \mathrm{~g}^{-1}$ & 19.025 & 41.379 & 30.380 & 7.586 & 11.186 & 30.878 & 20.363 & 5.512 \\
\hline $\mathrm{CaCO}_{3} \%$ & - & - & - & - & - & - & - & - \\
\hline $\mathrm{AS}, \%$ & 16.24 & 28.58 & 24.5695 & 3.4039 & 15.07 & 29.39 & 22.4785 & 4.5401 \\
\hline DO, $\%$ & 1,56 & 23.58 & 8.865 & 6.5929 & 3.84 & 18.13 & 8.4215 & 4.1135 \\
\hline $\mathrm{EO}, \%$ & 1.99 & 41.81 & 15.289 & 13.2654 & 3.66 & 29.29 & 13.1295 & 8.9025 \\
\hline $\mathrm{K}$ faktörü & 0.0004 & 0.0161 & 0.0065 & 0.0055 & 0.0016 & 0.0221 & 0.0125 & 0.0057 \\
\hline
\end{tabular}

EC:Elektriksel iletkenlik; OM:Organik Madde; TK:Tarla Kapasitesi; SN:Solma Noktasi; KDK:Katyon Değişim Kapasitesi; $\mathrm{CaCO}_{3}$;Kireç; AS:Agregat Stabilitesi; DO:Dispersiyon Oranı; $\quad \mathrm{K}: \mathrm{K}$ Faktörü; EO: Erozyon Oranı

$\mathrm{Bu}$ verilerin incelenmesinden de görüleceği üzere; konvansiyonel çay tarım yapılan toprakların kum içerikleri \%43.47 ile 72.48 , silt içerikleri $\% 16.56$ ile 30.39 ve kil içerikleri ise \%10.91 ile 26.18 arasında değişim göstermekte olup toprakların 12 adedi kumlu tın (SL), 6 adedi kumlu killi tın (SCL) ve 2 adedi tın (L) tekstür sınıflarında yer almaktadır. Organik çay tarımı yapılan toprakların ise kum içerikleri \%51.78 ile 75.99, silt içerikleri \%11.74 ile 26.99 ve kil içerikleri \%8.28 ile 23.52 arasında değişim göstermekte olup toprakların bünyesel dağılım bakımından 16 adedi kumlu tın (SL), 2 adedi tınlı kum (LS), 2 adedi kumlu killi tın (SCL), tekstür sinıflarına girmektedirler. Tekstür sinıfları bakımından konvansiyonel ve organik tarım yapılan topraklar genelde hafif bünyelidirler. Çay bitkisi yetiştiriciliği bakımından kumdan kile değin değişen tekstür aralığına sahip, derin, drenaj sorunu bulunmayan, besin elementlerince zengin topraklar tercih edilmektedir (Buçan, 2014). Derin olmayan ve sıkışmış tabaka içeren topraklar kök gelişimini sınırlandırdığı için tercih edilmemektedir. Tekstürel açıdan değerlendirme yapıldığında konvansiyonel ve organik tarım yapılan parsellerin her ikisinin de tekstürel dağılım açısından benzerlik gösterdiği, aralarında önemli bir farklılığın bulunmadığı ve çay tarımı için uygun yapıda oldukları ifade edilebilir (Phukan ve Baruah, 2015).

Konvansiyonel çay tarımı yapılan alanlardaki toprakların $\mathrm{pH}$ değerleri 4.12 ile 6.72 arasında değişmekte olup ortalama değer 5.04 olarak saptanmıştır (Çizelge 2). Örneklerin 4 tanesi fevkalade asit, 8 tanesi çok kuvvetli asit, 4 tanesi kuvvetli asit, 2 tanesi hafif asit, 2 tanesi nötr olarak tespit edilmiştir. Organik çay tarımı yapılan alanlardaki toprakların $\mathrm{pH}$ değerleri ise 4.5 ile 7.5 arasında değişmekte olup ortalama değerin 5.36 olduğu saptanmıştır (Çizelge 2). Örneklerin 10 tanesi çok kuvvetli asit, 4 tanesi kuvvetli asit, 4 tanesi hafif asit, 2 tanesi nötr olarak tespit 
edilmiştir. Çay bitkisinin gelişimi açısından optimum pH değeri 4.5-6.0 arasındadır. pH'nın asit ya da alkali yönde değişimi bitki gelişimini olumsuz yönde etkilemektedir (Kacar, 1994; Sarımehmet ve Mahmutoğlu, 1991). Araştırma konusu örnekler bu açıdan değerlendirildiğinde organik tarım uygulamalarının yapıldığı örneklerden nötr reaksiyona sahip olan 2 örneğin alındığı parsel optimum $\mathrm{pH}$ aralığının dışında kalmaktadır. Konvansiyonel tarım yapılan alanlardaki örnekler aynı açıdan irdelendiğinde fevkalade asit reaksiyona sahip 8 örneğin alındığı parseller $\mathrm{pH}$ aralığı açısından bitki gelişimini kısıtlayıcı durumdadir.

Konvansiyonel çay tarım yapılan alanlardaki toprakların elektriksel iletkenlik değerleri $0.265 \mathrm{dS} / \mathrm{m}$ ile $0.818 \mathrm{dS} \mathrm{m}^{-1}$ arasında değişmekte olup ortalama değer $0.452 \mathrm{dS} \mathrm{m}^{-1}$, dır (Çizelge 2). Organik çay tarımı yapılan alanlardaki toprakların elektriksel iletkenlik değerleri ise $0.579 \mathrm{dS} \mathrm{m}^{-1}$ ile $0.666 \mathrm{dS} \mathrm{m}^{-1}$ arasında değişmekte olup ortalama değer $0.319 \mathrm{dS} \mathrm{m} \mathrm{m}^{-1}$ dir (Çizelge 2). Konvansiyonel ve organik tarım uygulamalarının yapıldığı parsellerden alınan örneklerin ortalama tuz içerik değerleri mukayese edildiğinde konvansiyonel çay tarımı yapılan parsellerin daha yüksek tuz içeriğine sahip oldukları görülmektedir .(Çizelge 2). Toprakların tuzluluk yönünden sınıflandırılmasına ilişkin kaynaklar dikkate alındığında (Hazelton ve Murphy, 2007) toprakların tamamı tuzsuz sinifinda yer almakta olup tuzluluk yönünden genel anlamda herhangi bir sorunun olmadığ 1 ifade edilebilir.

Konvansiyonel çay tarım yapılan alanlardaki toprakların organik madde içerikleri 4.19 ile 13.51 arasında değişmekte olup ortalama değer $8.75^{\prime}$ tir (Çizelge 2). Örneklerin 8 tanesi fazla, 12 tanesi çok fazla sınıfında organik madde içermektedirler. Organik çay tarım yapılan alanlardaki toprakların organik madde içerikleri ise 2.19 ile 10.65 arasında değişmekte olup ortalama değer 5.76 'dır. Örneklerin 3 tanesi orta, 7 tanesi fazla, 10 tanesi çok fazla sınıfında organik madde içermektedirler. Gerek organik tarım uygulamalarının ve gerekse konvansiyonel tarım uygulamalarının yapıldığı parsellere ait örneklerin organik madde yönünden yeterli düzeyde oldukları, başka bir ifade ile organik madde ile ilgili bir sorunun bulunmadığı tespit edilmiştir. Organik ve konvansiyonel tarım uygulamalarının yapıldığı parsellerin ortalama organik madde içerikleri dikkate alındığında konvansiyonel tarım yapılan toprakların (8.75) organik tarım yapılan topraklara (5.76) göre daha yüksek düzeyde organik madde içeriğine sahip oldukları tespit edilmiştir (Çizelge 2). Çelişkili görünen bu durum muhtemelen organik tarım uygulamalarının geçiş süreci içerisinde (3. yılında) bulunmasına bağlı olarak oluşan yeniden şekillenme ve iklimsel koşullarla ile ilişkilidir (Er ve Başalma, 2008).

Konvansiyonel çay tarımı yapılan alanlardaki toprakların KDK içerikleri ise 19.025 ile 41.379 arasında değişmekte olup ortalama değer 30.380 'dir (Çizelge 2). Örneklerin yine tamamına yakını KDK içerikleri bakımından zengin olarak değerlendirilmektedir (Hazelton ve Murphy (2007). Organik çay tarımı yapılan alanlardaki toprakların KDK (me/100g toprakta) değerleri 11.186 ile 30.878 arasında değişmekte olup ortalama değer 20.363'tür (Çizelge 2). Örneklerin tamamına yakını KDK içerikleri bakımından zengin sınıfı içerisinde yer almaktadırlar (Hazelton ve Murphy (2007). Organik ve konvansiyonel tarım yapılan parsellere ait örneklerin ortalama KDK ve değişebilir katyon içerikleri incelendiğinde organik tarım yapılan parsellerin daha düşük KDK değerlerine sahip olduğu görülmektedir (Çizelge 2). Bu durum muhtemelen toprakların tekstürel ve organik madde içeriklerindeki farklılıktan kaynaklanmış olabilir. Iğdır Ovası yüzey topraklarının fiziksel ve kimyasal özellikleri arasındaki ilişkileri inceleyen Özdemir (1987), kil ve organik madde içeriği ile KDK değerleri arasında pozitif bir ilişkinin bulunduğunu vurgulamıştır.

Konvansiyonel çay tarımı yapılan alanlardaki toprakların tarla kapasitesi içerikleri 17.98 ile 37.75 arasında değişmekte olup ortalama değer 27.64'tür. Solma noktası nem içerikleri ise 11.7 ile 28.10 arasında olup ortalama 18.41 'dir (Çizelge 2). Organik çay tarımı yapılan alanlardaki toprakların tarla kapastesi nem içerikleri ise 13.21 ile 24.73 arasında değişmekte olup ortalama değer 17.90 'dır. Solma noktası nem içerikleri ise 6.08 ile 17.97 arasında olup ortalama değer 10.04'tür (Çizelge 2). Organik ve konvansiyonel tarım yapılan parsellere ait örneklerin ortalama tarla kapasitesi ve solma noktası değerleri irdelendiğinde konvansiyonel tarım yapılan parsellerin organik tarım yapılan parsellere göre daha yüksek tarla kapasitesi ve solma noktası değerlerine sahip oldukları görülmektedir (Çizelge 2). Bu durum muhtemelen konvansiyonel tarım yapılan parsellerin daha yüksek organik madde içeriğine ve daha ince tekstüre sahip olmasından kaynaklanmış olabilir. Karahan ve ark. (2013) bu doğrultuda yaptıkları bir çalışmada toprak bileşenlerinin nem sabiteleri üzerine etkisini irdelemişlerdir. Araştıııcılar çalışma sonunda topraktaki kil ve organik madde içeriği ile nem sabiteleri arasında pozitif ilişkiler belirlemişlerdir.

\subsection{Erozyona duyarlılık parametreleri}

\subsubsection{Dispersiyon oranı}

Konvansiyonel ve organik tarım uygulamalarının yapıldığı ve farklı konumlarda bulunan arazilerden alınan toprak örneklerinde belirlenen dispersiyon oranı değerlerine ilişkin tanıtıcı istatistiksel analiz sonuçları Çizelge 2'de, kil içeriği ile dispersiyon oranı değerleri arasındaki ilişkiler ise Şekil 1'de verilmiştir. Bu verilerin incelenmesinden de anlaşlacağı üzere dispersiyon oranı değerleri konvansiyonel tarım uygulamalarının yapıldığ 1 parsellerde $\% 1.56$ ile \% 23.58 arasında değişmekte olup ortalama değer $8.865^{\prime}$ tir. $\mathrm{Bu}$ oran değeri, 1slanma sonucunda toprak strüktüründe meydana gelen deformasyonu yansitmakta olup \%15'ten küçük oran değerine sahip topraklar 
erozyona karşı dayanıklı olarak değerlendirilmektedir (Morgan, 2005). Bu sınır değeri esas alınacak olursa uygulama alanındaki örneklerden 400 ve $440 \mathrm{~m}$ rakımlarında yer alan 3 ve 4 ile 15 ve 16 numaralı örnekler \%15'in üzerinde oran değerlerine sahip olup erozyona karşı duyarlı; diğerleri ise dayanıklı olarak değerlendirilebilir. Organik tarım uygulamalarının yapıldığı parsellerdeki dispersiyon oranı değerleri ise
\%3.84 ile \%18.13 arasında değişmekte olup ortalama değer 8.42 'dir. Organik tarım uygulamalarının yapıldığı parsellerden mikrobiyal gübrelemenin yapıldığı ve 120 $\mathrm{m}$ rakımda yer alan 31 ve 32 numaralı örnekler erozyona karşı duyarl1; diğerleri ise erozyona karşı dayanıklı olarak değerlendirilebilir.

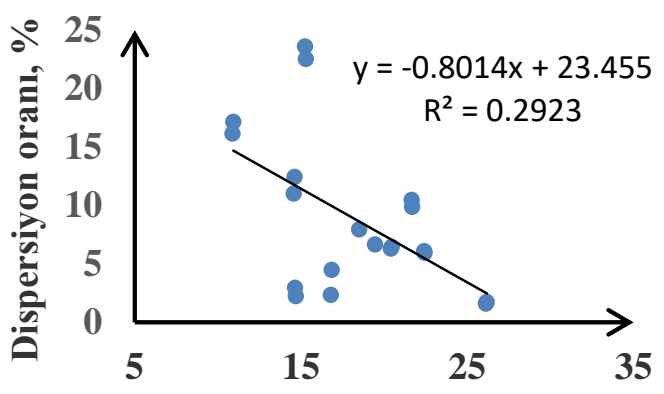

a)

Kil içeriği, \%

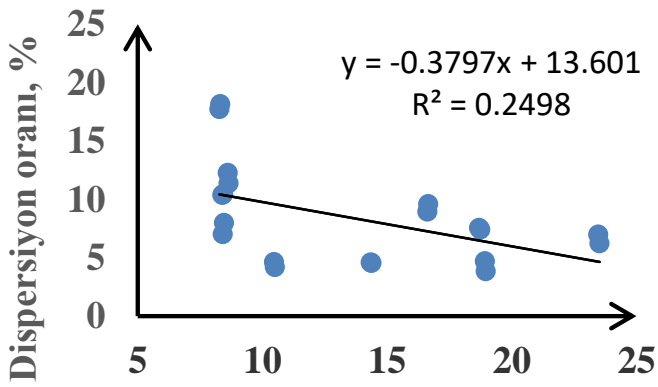

b) Kil içeriği, \%

Şekil 1 Toprakların kil içerikleri (a-konvansiyonel tarım alanları, b-organik tarım alanları) ile dispersiyon oranı değerleri arasındaki ilişsiler

Konvansiyonel ve organik uygulamaların yapıldı̆̆ topraklar birbirleri ile mukayese edildiklerinde (Çizelge 2, Şekil 1) ortalama değerler doğrultusunda organik tarım uygulamalarının yapıldığı parsellere ait örneklerin erozyona karşı daha dirençli oldukları ifade edilebilir.

Toprakların kil $(\mathrm{r}=-0.430)$, silt $(0.478)$ ve organik madde ( $r=-0.457)$, içeriği ile dispersiyon oranı değerleri arasında \%1 düzeyinde önemli negatif, kum içeriği $(\mathrm{r}=0.589)$ arasında da \% 1 düzeyinde önemli pozitif korelasyonlar elde edilmiştir (Çizelge 3). Chandra ve De (1978), Dulkadiroğlu (2017), Sönmez ve Özdemir
(1988), Morgan (2005) ve Öztürk (2013) yapmış oldukları çalışmalarda burada elde edilen neticeleri destekleyici sonuçlar elde etmişlerdir. Toprakların $\mathrm{KDK}, \mathrm{TK}, \mathrm{SN}$, değerleri ile dispersiyon oranı değerleri arasında önemli bir ilişki kaydedilememiştir.

Diğer taraftan toprakların dispersiyon oranı değerleri ile erozyona karşı duyarlılığın değerlendirilmesinde kullanılan $\mathrm{K}$ faktörü, değerleri arasında önemli pozitif, agregat stabilitesi değerleri arasında ise önemli negatif ilişkiler elde edilmiştir (Çizelge 3).

Çizelge 3. Toprak kalite parametreleri ve erozyona duyarlılık ölçütleri arasındaki ilişkiler.

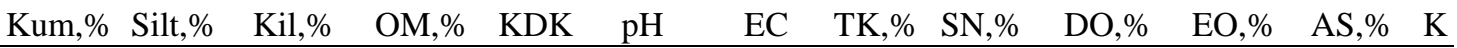

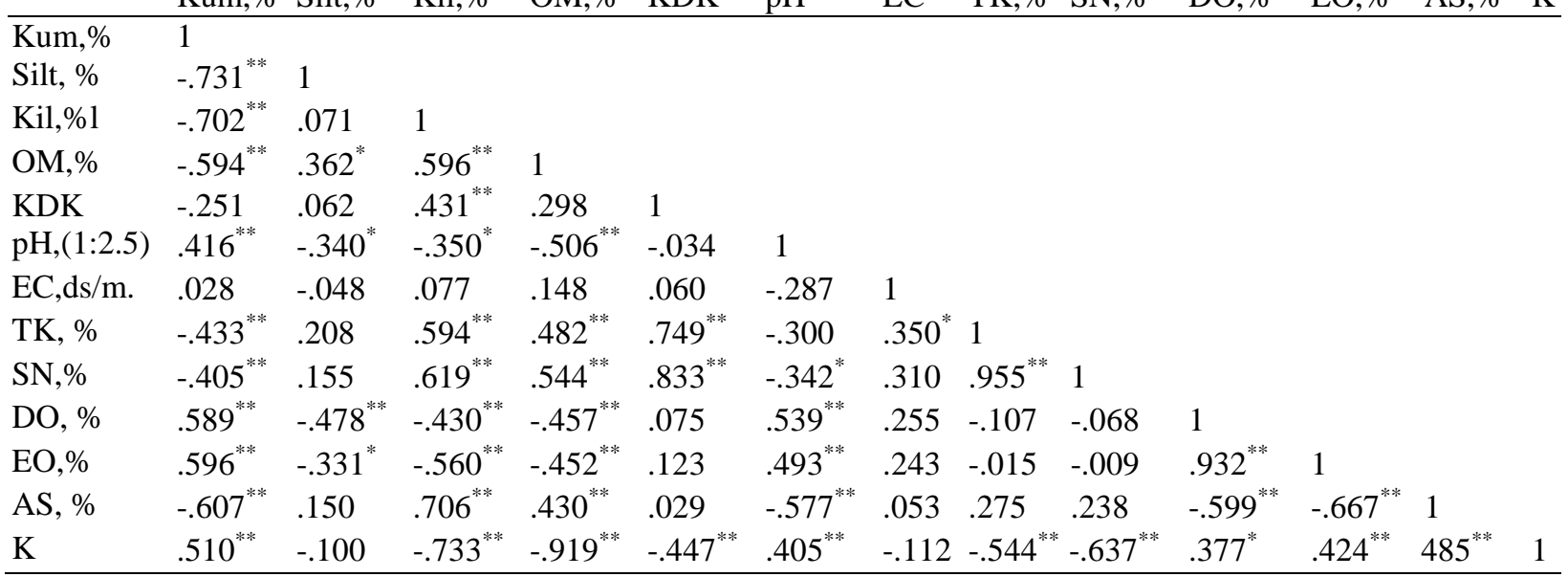

OM:Organik Madde; KDK: Katyon Değişim Kapasitesi me/100g ; TK:Tarla Kapasitesi; SN:Solma Noktası; DO:Dispersiyon Oranı; EO:Erozyon Oranı; K: K Faktörü; AS:Agregat Stabilitesi 


\subsubsection{Agregat stabilitesi}

Konvansiyonel ve organik tarım uygulamalarının yapıldığı ve farklı rakımlarda bulunan arazilerden alınan toprak örneklerinde belirlenen agregat stabilitesi değerlerine ilişkin istatistiksel değerler Çizelge 2'de ve agregat stabilitesi ile kil içerikleri arasındaki ilişkiler ise Şekil 2'de gösterilmiştir. Bu verilerin incelenmesinden de görüleceği üzere konvansiyonel tarım uygulamalarının yapıldığı parsellere ait toprak örneklerinde agregat stabilitesi değerleri \%16.24 ile \%28.58 arasında değişmekte olup ortalama değer

\subsection{6'dir.}

Kil içeriği yüksek olan 20 numaralı (26.18) örneğin agregat stabilitesi değeri 26.53 ve kil içeriği düşük olan 12 numaralı(10.91) örneğin agregat stabilitesi değeri ise $(23,6)$ olarak belirlenmiştir. Organik tarım uygulamalarının yapıldı $\breve{g} 1$ parsellere ait örneklerin agregat stabilitesi değerleri ise \%15.07 ile \%29.39 arasında değișmekte olup ortalama değer 22.47 'dir. Kil içeriği yüksek olan 9 numaralı örneğin agregat stabilitesi değeri en büyük (29.39) ve kil içeriği düşük olan 4 numaralı örneğin agregat stabilitesi değeri ise en küçük (15.07) olarak belirlenmiştir.

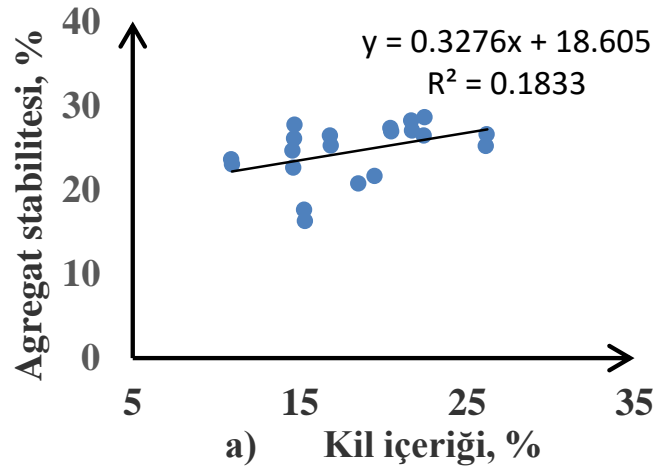

Şekil 2. Toprakların kil içerikleri (a-konvansiyonel tarım alanları, b-organik tarım alanları) ile agregat stabilitesi değerleri arasındaki ilişkiler

Agregat stabilitesi değeri tarımsal uygulama ve işlemlerin toprak yapısı üzerindeki etkilerinin değerlendirilmesinde, erozyona karşı duyarlılığın irdelenmesinde kullanılan önemli bir parametre olup erozyonla ilgili değerlendirmeler için bir sınır değer tespit edilememiştir. Stabilite değerleri arttıkça erozyona karşı duyarlılık azalmaktadır.(Özdemir, 2013). Konvansiyonel ve organik tarım uygulamalarının yapıldığı topraklar birbirleri ile mukayese edildiklerinde ortalama değerler doğrultusunda konvansiyonel uygulamalarının yapıldığ 1 parsellere ait örneklerin erozyona karşı daha dirençli oldukları ifade edilebilir. Gerek organik ve gerekse konvansiyonel tarım uygulamalarının yapıldığı parsellerde kum içeriği yüksek olan parsellerin erozyona karş1 daha duyarlı oldukları tespit edilmiştir.

Toprakların kum $(\mathrm{r}=-0.607)$ içeriği ile agregat stabilitesi arasındada \%1 düzeyinde önemli negatif, kil $(\mathrm{r}=0.706)$ ve organik madde $(\mathrm{r}=0.430)$ içeriği ile agregat stabilitesi değerleri arasında \%1 düzeyinde, önemli pozitif korelasyonlar belirlenmiştir. (Çizelge 3). Chandra ve De (1978), Asskın (1997), Morgan (2005) ve Öztürk (2013) yapmış oldukları çalışmalarda burada elde edilen bulgulara benzer sonuçlar belirlemişlerdir.

Diğer taraftan toprakların agregat stabilitesi değerleri ile erozyona karşı duyarlılığın

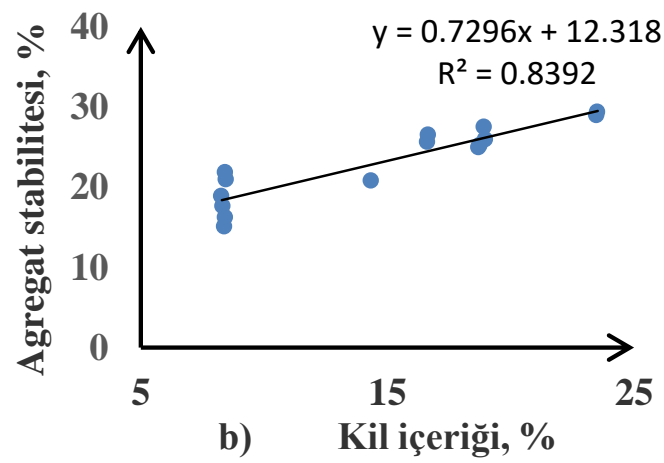

değerlendirilmesinde kullanılan; dispersiyon oranı, erozyon oranı, $\mathrm{K}$ faktörü, değerleri arasında ise önemli negatif ilişkiler elde edilmiştir (Çizelge 3) .

\subsection{K faktörü}

Konvansiyonel ve organik tarım uygulamalarının yapıldığı ve farklı rakımlarda bulunan arazilerden alınan toprak örneklerinde belirlenen aşınım faktörü değerlerine ilişkin istatistiksel değerler Çizelge 2'de ve bu değerler ile kil içerikleri arasındaki ilişkiler ise Şekil 3 'de verilmiştir. $\mathrm{Bu}$ verilerin incelenmesinden de anlaşılacağı üzere $\mathrm{K}$ faktörü değerleri konvansiyonel tarım yapılan parsellerden alınan toprak örneklerinde 0.0004 ile 0.0161 arasında değişmekte olup ortalama değer 0.0065 'tir. Organik tarım uygulamalarının yapıldığg toprak örneklerinde belirlenen $\mathrm{K}$ faktörü değerleri ise \% 0.0016 ile $\% 0.0221$ arasında değişmekte olup ortalama değer $0,0125^{\prime}$ tir.

Toprak aşınım faktörü değeri toprağın tekstür, strüktür, organik madde içeriği ve su geçirgenliği değerleri ile tarımsal uygulama ve bitki yönetimine ilişkin işlemlerden önemli ölçüde etkilenen bir parametre olup toprağın erozyona uğrama eğilimini yansitmaktadır (Morgan, 2005; Özdemir, 2013). Topraklar, aşınım faktörü değerlerine göre çok az ve 
çok fazla arasında değişen 5 farklı (Çizelge 4) sınıf içerisinde değerlendirilmektedir(Morgan, 2005). Bu sınır değerleri esas alınacak olursa araştırma yapılan konvansiyonel ve organik tarım topraklarının tamamı çok az aşınabilir sınıfı içerisinde yer almaktadırlar. Bu durum muhtemelen tarımı yapılan çay bitkisinin toprak yüzeyini tamamen kaplama özelliğinde olması, toprağın organik madde içeriği ve tekstürel yapıdan kaynaklanmaktadır (Özdemir, 2013).

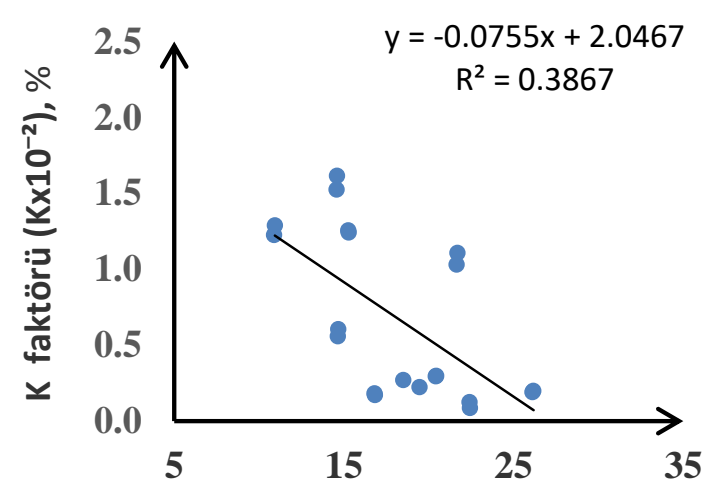

a)

Kil içeriği, \%

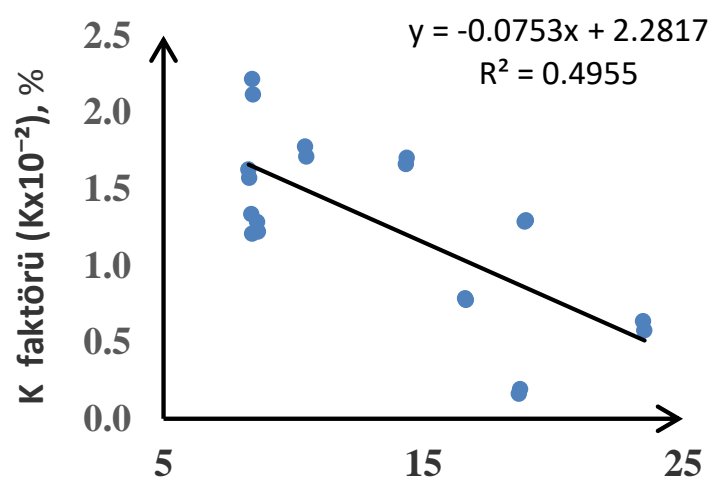

b) Kil içeriği, \%

Şekil 3. Toprakların kil içerikleri (a-konvansiyonel tarım alanları, b-organik tarım alanları) ile K faktörü değerleri arasındaki ilişkiler

Çizelge 4. Toprakların aşınım faktörü (K) değerlerine göre sınıflandırılması

\begin{tabular}{ll}
\hline Aşınım faktörü (K) değeri & Aşınabilirlik derecesi \\
\hline $0.00<\mathrm{K} \leq 0.05$ & Çok az aşınabilir topraklar \\
$0.05<\mathrm{K} \leq 0.10$ & Az aşınabilir topraklar \\
$0.10<\mathrm{K} \leq 0.20$ & Orta derecede az aşınabilir topraklar \\
$0.20<\mathrm{K} \leq 0.40$ & Fazla derecede az aşınabilir topraklar \\
$0.40<\mathrm{K} \leq 0.60$ & Çok fazla derecede aşınabilir topraklar \\
\hline
\end{tabular}

Konvansiyonel ve organik tarım uygulamalarının yapıldığı topraklar birbirleri ile mukayese edildiklerinde ortalama değerler doğrultusunda konvansiyonel uygulamalarının yapıldığ parsellere ait örneklerin erozyona karşı daha dirençli oldukları ifade edilebilir.

Toprakların kil içeriği $(\mathrm{r}=-0.734)$, organik madde $(\mathrm{r}=-0.920), \mathrm{KDK}(\mathrm{r}=-0.466)$, TK $(\mathrm{r}=-0.617)$ ve SN ( $\mathrm{r}=-$ 0.621 ) değerleri ile $\mathrm{K}$ faktörü arasında $\% 1$ düzeyinde önemli; azot $(r=-0.389)$ ve fosfor $(r=-0.357)$ içerikleri arasında $\% 5$ düzeyinde önemli negatif korelasyon görülürken kum ( $\mathrm{r}=0.522)$ içeriği ile $\mathrm{K}$ faktörü arasında \%1 düzeyinde önemli pozitif bir ilişki elde edilmiştir. (Çizelge 3). Bryan (1968), Chandra ve De (1978), Ngatunga vd (1984), Aşkın (1997), Sönmez ve Özdemir (1988) ve Morgan (2005) yapmış oldukları çalışmalarda burada elde edilen bulguları destekleyici sonuçlar bulmuşlardır.

Diğer taraftan toprakların $\mathrm{K}$ faktörü değerleri ile erozyona karșı duyarlılı̆̆ın değerlendirilmesinde kullanılan dispersiyon oranı, erozyon oran1, kil rasinda önemli pozitif; agregat stabilitesi değerleri arasında önemli negatif ilişkiler belirlenmiştir (Çizelge3).

\section{Sonuçlar ve Öneriler}

$\mathrm{Bu}$ araştırma Rize ili koşullarında konvansiyonel (inorganik) ve organik çay tarımı uygulamalarının bazı toprak kalite parametreleri ve erozyona karşı duyarlılık üzerine etkilerini belirlemek üzere yürütülmüsstür. Çalışmada aynı hat üzerinde ve farklı konumlarda (20) yer alan, organik ve geleneksel tarım uygulamalarının yapıldığ 1 çay bahçelerinden 40 adet yüzey $(0-20 \mathrm{~cm})$ toprak örneği alınmıştır. Bu örnekler üzerinde yapılan analiz ve değerlendirmeler sonucunda;

1. Konvansiyonel ve organik tarım uygulamalarının kalite parametreleri üzerine etkilerinin rakımdan etkilendiği, toprakların tamamının hafif bünyeli olduğu, genelde yüksek rakımlarda yer alan parsellerin daha yüksek organik madde ve kil içeriğine sahip oldukları belirlenmiş̧ir. Erozyona uğrama eğiliminin de genelde eğim ve rakımdan etkilendiği, gerek organik ve gerekse konvansiyonel tarım uygulamaların yapıldığı parsellerde yüksek rakımlarda ve düşük eğimlerde yer alan örneklerin erozyona karşı daha dirençli oldukları tespit 
edilmiştir.

2. Konvansiyonel tarım uygulamalarının yapıldı ğ parsellerin organik tarım uygulamalarının yapıldığ parsellere göre ortalama olarak daha uygun toprak kalite koşullarına sahip oldukları görülmüştür. $\mathrm{Bu}$ durum muhtemelen organik uygulamaların geçit aşamasında (3. yılında) olması ve adaptasyon süreci ile ilişkilidir.

3. Araştırma konusu (organik ve konvansiyonel) toprakların kil, silt+kil, kum, organik madde içeriği, katyon değişim kapasitesi pH, EC, tarla kapasitesi, solma noktası gibi temel toprak özellikleri ile strüktürel dayanıklılığı ve erozyona karşı duyarlılığı ortaya koymada esas alınan ölçütlerle dispersiyon oranı, K faktörü, agregat stabilitesi gibi ölçütler arasında istatistiksel bakımdan önemli ilişkiler elde edilmiştir.

4. Diğer taraftan pratiğe yönelik sağlıklı önerilerin yapılması açısından çalışmanın çay tarımının yapıldı ğı farklı bölgeleri ve farklı uygulama yıllarını da içerecek şekilde devam ettirilmesinde yarar vardır

\section{Kaynaklar}

Akçanal, Ödün. N., 2013. Fırtına Vadisi'nde (Çamlıhemşin-Rize) çay tarımında kullanılan suni ve doğal gübrelerin oluşturduğu su kirliliğinin akuatik ekosisteme etkisi. Yüksek Lisans Tezi. Recep Tayyip Erdoğan Üniversitesi Fen Bilimleri Enstitüsü, 76s, Rize.

Anonim, 2014, Çay,Vikipedi,http://tr,wikipedia,org /wiki/\%C3\%87ay_\%28bitki\%29-(Erişim tarihi: 06.Mart 2014).

Anonim, 2018. https://www.haritatr.com/cayeli-haritasii2c1 (Erişim tarihi: 12.Ağustos.2018)

Aşkın, T., 1997. Ordu ili toprakların strüktürel dayanıklılığının ve aşınıma duyarlılığının belirlenmesi üzerine bir araştırma. Yüksek Lisans Tezi. Ondokuz Mayıs Üniversitesi Fen Bilimleri Enstitüsü, 44s, Samsun.

Bayrakl1, F., 1987. Toprak ve bitki analizleri, OMÜ Yayınları, No 17, Samsun.

Bryan, R. B., 1968. The development, use and efficiency of indices of soil erodibility. Geoderma, 2: 5-26.

Buçan, Ö., 2014. Çay topraklarındaki makro ve mikro elementlerin mevsimsel değişimi. Yüksek Lisans Tezi. T.C. Recep Tayyip Erdoğan Üniversitesi Fen Bilimleri Enstitüsü, Kimya Anabilim Dalı, 104s, Rize

Chandra, S., De., S, K., 1978. A Simple Laboratory apparatus to measure relative erodibility of soil, Soil Science, 25: 115-119.

Demiralay, İ., 1993. Toprakta fiziksel analizler. Atatürk Üniversitesi Ziraat Fak, Yayınları No: 143,:90-95, Erzurum.

Dulkadiroğlu, M., 2017. Farklı topoğrafik pozisyonlarda oluşmuş toprakların bazı fiziksel ve kimyasal özellikleri ile erozyona duyarlılık ölçütleri arasındaki ilişkiler. Yüksek Lisans. Tezi Ondokuz
Mayıs Üniversitesi, Fen Bilimleri Enstitüsü, 61s, Samsun

Er, C. ve D. Başalma, 2008. Organik tarımdaki gelişmeler. Nobel Yayın Dağıtım No:1354, Ankara.

Hazelton, P., Murphy, B., 2016. Interpreting soil test results: What do all the numbers mean?. CSIRO publishing, Clayton, South VIC, Australia .

Kacar, B., 1994. Bitki ve toprağın kimyasal analizleri III. Toprak analizleri. Ankara Üniversitesi, Ziraat Fakültesi Eğitim Araştırma ve Geliştirme Vak, Yay,No:3, Ankara.

Karahan, G., Erşahin, S., Öztürk, S., 2013. Toprak koşullarına bağlı olarak tarla kapasitesi dinamiği, Gaziosman Paşa Üniversitesi Ziraat Fakültesi Dergisi, 30 (1):1-9.

Leaungvutivirog, C., Sunantapongsuk, V., Limtong, P., Nakapraves, P., Piriyaprin, S., 2002. Effect of organic fertilizers on soil Improvements in Mab Bon, Tha Yang, Satuk, and Renu Series for Corn Cultivation in Thailand. 17th World Congress of Soil Science, 14-21 August 2002, Thailand, Symposium No: 57, Paper No, 1899.

Lowery, B., Swan, J., Schumacher, T.,Jones, A., 1995. Physical properties of selected soils by erosion class. J. Soil and Water Conserv, 50: 306-311.

Mokma, D.L., Fenton, T.E., Olson, K.R., 1996. Effect of erosion on morphology and classification of soils in the North Central United States. J, Soil Water Conserv, 51: 171-176.

Morgan, R. P. C., 2005. Soil erosion and conservation. Blackwell Publishing Ltd. ISBN 1-4051-1781-8.

Ngatunga, EN. R., Singer MJ, 1984. Effect of surface management on runoff and soil erosion from some plot milangano. Geoderma, (33):1-12.

Özdemir, N., 2013, Toprak ve su koruma. Ondokuz Mayıs Üniversitesi Ziraat Fakültesi Yayınları, No: 22, Üçüncü Bask1, 232s, Samsun.

Özdemir, N., 1987. Iğdır ovası yüzey topraklarının bazı fiziksel ve kimyasal özellikleri ile strüktürel dayanıklılık ve erozyona duyarlılık parametreleri arasındaki ilişkiler, Yüksek Lisans Tezi, Atatürk Üniversitesi Fen Bilimleri Enstitüsü, 40s, Erzurum.

Öztürk, E., 2013. Organik Düzenleyicilerin Toprak kaybı ve toprak kalitesi üzerindeki etkilerinin laboratuvar koşullarında belirlenmesi. Doktora Tezi. Ondokuz Mayıs Üniversitesi Fen Bilimleri Enstitüsü, 151s, Samsun.

Phukan, I.Kr., Baruah, A., 2015. Studies on soil physical, chemical and microbiological properties under compacted and non-compacted tea soils of south bank. International Journal of Science, Environment and Technology, Vol, 4, No 1: 253 263.

Ray, S..K., Mukhopadhyay, D., 2012. A Study on physicochemical properties of soils under different tea growing regions of West Bengal (India). International Journal of Agriculture Sciences, Volume 4 (8): 325-329. 
Saha, A.K., Biswas, A., Khan, A.Q., Farazi, M., Rahma, H., 2014. Improvement of tea (Camellia sinensis 1,) soil properties by growing different green crops. The Agriculturists, 12(2), 34-38.

Sarımehmet, M., Mahmutoğlu, H., 1991. Çayın gübrelenmesi ile ilgili bazı görüş ve öneriler. ÇayKur Dergisi, :4, 16-20..

Sönmez, K., Özdemir, N., 1988. Iğdır ovası yüzey topraklarının bazı fiziksel ve kimyasal özellikleri ile strüktürel dayanıklılık ve erozyona duyarlılık parametreleri arasındaki ilişkiler. Atatürk
Üniversitesi. Ziraat Fakültesi Dergisi, 19(1-4): 155165.

Turan, M., İnce, E., İlçi, F., 2015. Çay raporu. Available at http://www.caykur.gov.tr/uploads/Yay\%C4\% B1nlar/CAYARGERAPORU2015-1.pdf (Erişim tarihi: 20 Mart 2019).

U.S.Salinity Lab, Staff., 1954, Diagnosis and 1mprovement, of saline and alkali soils, USDA Agriculture handbook, No: 60.

Wischmeier, WH., Smith, DD., 1978. Predicting rainfall erosion losses a guide to conservation planning. Agriculture Handbook No : 557, England. 